The Agriculturists 18(1): 31-41 (2020) ISSN 2304-7321 (Online), ISSN 1729-5211 (Print)

A Scientific Journal of Krishi Foundation

Indexed Journal

DOI: https://doi.org/10.3329/agric.v18i1.49457

\title{
Determination of Nutrient Accumulation Pattern of New Aromatic Rice (Oryza sativa L.) as Influenced by Different Applied Fertilizers and Plant Spacing
}

\author{
A.K.M. Alauddin Chowdhury ${ }^{1}$, Md. Nurul Huda Al Mamun ${ }^{2} *$, Md. Khairul Islam ${ }^{2}$ and \\ Md. Mohashin Farazi ${ }^{2}$ \\ ${ }^{1}$ Department of Agricultural Extension, Khamar Bari, Farmgate, Dhaka \\ ${ }^{2}$ Soil Resource Development Institute, Krishi khamar Sarak, Farmgate, Dhaka \\ *Corresponding author and Email: nhalmamun@gmail.com
}

Received: 07 November 2019

Accepted: 25 June 2020

\begin{abstract}
Field and laboratory experiments were conducted at the Bangabandhu Sheikh Mujibur Rahman Agricultural University, Gazipur, during boro season of 2015-2016 to determine the response of rice crop (BU Dhan 2) to different plant densities under different fertilizer levels. The variety was grown with three fertilizer levels viz. recommended (57-10-8-7-0.9 $\left.\mathrm{kg}^{\mathrm{NPKSZn}} \mathrm{ha}^{-1}\right), 50 \%$ higher (114-2016-14-1.8 kg NPKSZn ha ${ }^{-1}$ ) and 50\% lower (28.5-5-4-3.5-0.45 $\left.\mathrm{kg} \mathrm{NPKSZn} \mathrm{ha}^{-1}\right)$ than recommended level and three plant spacing $(20 \mathrm{~cm} \times 25 \mathrm{~cm}, 20 \mathrm{~cm} \times 20 \mathrm{~cm}$ and $20 \mathrm{~cm} \times 15 \mathrm{~cm})$ representing wider, standard and closer plant densities. Nutrient uptake of the variety was higher at higher level of fertilizer and closer plant spacing. The highest grain yield $5.18 \mathrm{t} \mathrm{ha}^{-1}$ of the variety was associated with the highest nutrient uptake under higher dose of fertilizer at closer plant spacing. This treatment combination also showed the highest nitrogen $\left(86.53 \mathrm{~kg} \mathrm{ha}^{-1}\right)$, phosphorus $\left(9.85 \mathrm{~kg} \mathrm{ha}^{-1}\right)$, potassium $\left(103.9 \mathrm{~kg} \mathrm{ha}^{-1}\right)$, sulphur $\left(12.27 \mathrm{~kg} \mathrm{ha}^{-1}\right)$ and zinc uptake $\left(265.76 \mathrm{~g} \mathrm{ha}^{-1}\right)$ of the variety, although nutrient use efficiency was higher at lower fertilizer level under wider plant density.
\end{abstract}

Keywords: New aromatic rice, plant spacing, fertilizer level

\section{Introduction}

Rice is the main cereal crop, which ranks first position in Bangladesh. It occupies nearly $75 \%$ of total cropped area of the country (BBS, 2015). More than $99 \%$ of the people of the country consume rice as their main food at the rate of $416 \mathrm{~g}$ per person per day (HEIS, 2010). It is main source of energy, which supplies about $75 \%$ of calories intake daily diet (Bhuiyan et al., 2004). It also provides vitamin and other nutrients to the common people consuming rice as a staple food. Rice production in the country is increasing but emphasis was given mostly on yield improvement. Currently, people are becoming more conscious about the quality of rice they consume. Therefore, it is desirable to increase yield as well as quality of rice. The new rice variety (BUdhan 2) developed by Department of Genetics and Plant Breeding, BSMRAU is high grain quality with aromatic characteristics. This variety needs optimum plant nutrients as many soils of the country is inherently poor in nutrient content (Ahmed, 1992). The most common limiting nutrients in rice are nitrogen, phosphorus, potassium, sulphur, zinc and boron (Suriya-arunroj et al., 2000). 
Nitrogen is one of the essential macronutrients for rice growth and one of the main factors to be considered for developing a high yielding rice cultivar. The demand of the plant for other macronutrients mainly depends on the nitrogen supply (Dobermann et al., 1996). Rice plant normally responds to nitrogen fertilizers and in addition, some cases of responses to phosphorous, potassium, sulphur and zinc have been described (Ragland and Bunpukdee, 1987). Adequate supply of nitrogen is beneficial for nitrogen, carbohydrates and protein metabolism, promoting cell divisions and enlargement.

Similarly, good supply of phosphorus is usually associated with increased exploration and supply of nutrients and water to the growing plant parts, resulting in increased growth and yield traits, thereby ensuring more seed and dry matter yield (Matti and Jana, 1985). Potassium nutrition in rice promotes panicle development, spikelet fertility, leaf area and leaves longevity, stem strength and plant tolerance to diseases and pests. Sulphur plays an important role in the biochemistry and physiology of the rice plant, mainly in chlorophyll synthesis. Zinc is critical for many physiological functions including the maintenance of structural and functional integrity of biological membranes and the facilitation of protein synthesis (Singh et al., 2012).

Understanding the dynamics of these nutrients in terms of their uptake, translocation and distribution in rice plant is an important aspect of its nutrition that will improve its production and reduce the cost of fertilization. Besides nutrition, plant density is one of the most significant agronomic practices contributing towards grain yield as well as other important attributes of the crop. Rautaray (2007) reported that $15 \times 15 \mathrm{~cm}$ plant spacing resulted in highest grain yield of $4.51 \mathrm{t} \mathrm{ha}^{-1}$ during wet season and $5.27 \mathrm{t} \mathrm{h}^{-1}$ during dry season. Many studies have been conducted to elucidate the factors controlling nitrogen, phosphorus, potassium, sulphur and zinc uptake efficiencies and nutrient content in plants (Tillman et al.,1991) but there is scarce information on nutrient efficiency of new rice variety involving several plant densities. A study was, therefore, conducted to determine the response of rice crop (BUdhan 2) to different plant densities under different fertilizer levels.

\section{Materials and Methods}

Field and laboratory experiments were conducted at the Bangabandhu Sheikh Mujibur Rahman Agricultural University, Gazipur, during boro season of 2015-2016. The planting material was an aromatic rice variety (BUdhan2). The experiment having two factors (fertilizer level and plant spacing) was set up in a randomized complete block design with four replications. Fertilizer levels are 50\% higher 114-20-16-14$1.8 \mathrm{~kg} \mathrm{NPKSZn} \mathrm{ha}^{-1}$ ) than recommended dose $\left(\mathrm{F}_{1}\right)$, recommended (57-10-8-7-0.9 kg NPKSZn $\left.\mathrm{ha}^{-1}\right)$ dose $\left(\mathrm{F}_{2}\right)$ and $50 \%$ lower (28.5-5-4-3.5-0.45 $\left.\mathrm{kg} \mathrm{NPKSZn} \mathrm{ha}{ }^{-1}\right)$ than recommended dose $\left(\mathrm{F}_{3}\right)$ and three plant spacing such as wider, $20 \mathrm{~cm} \times$ $25 \mathrm{~cm}\left(\mathrm{~S}_{1}\right)$, standard, $20 \mathrm{~cm} \times 20 \mathrm{~cm}\left(\mathrm{~S}_{2}\right)$ and closer $20 \mathrm{~cm} \times 15 \mathrm{~cm},\left(\mathrm{~S}_{3}\right)$ plant densities. Compared treatments are $\mathrm{F}_{1} \mathrm{~S}_{1}$ : Higher dose of fertilizer application with wider spacing. $F_{1} S_{2}$ : Higher dose of fertilizer application with standard spacing, $\mathrm{F}_{1} \mathrm{~S}_{3}$ : Higher dose of fertilizer application with closer spacing, $\mathrm{F}_{2} \quad \mathrm{~S}_{1}$ : Recommended dose of fertilizer application with wider spacing, $\mathrm{F}_{2} \mathrm{~S}_{2}$ : Recommended dose of fertilizer application with standard spacing, $F_{2}$ $\mathrm{S}_{3}$ : Recommended dose of fertilizer application with closer spacing, $F_{3} S_{1}$ : Lower dose of fertilizer application with wider spacing, $F_{3} S_{2}$ : Lower dose of fertilizer application with standard spacing, $\mathrm{F}_{3} \mathrm{~S}_{3}$ : Lower dose of fertilizer application with closer spacing.

\subsection{Plant analysis}

Rice plant of five hills from each plot were sampled at 10 days interval from 30 DAT and continued till 90 DAT. Nitrogen, P, K, S and Zn were determined from the collected plant samples. The leaf sample was dried at $70^{\circ} \mathrm{C}$ for $72 \mathrm{hrs}$ and ground by Wiley Mill. The ground sample was digested in concentrated $\mathrm{H}_{2} \mathrm{PO}_{4}$ and total $\mathrm{N}$ concentration was determined by micro 
Kjeldahl method (Yoshida et al., 1976). The concentration of $\mathrm{P}, \mathrm{K}, \mathrm{S}$ and $\mathrm{Zn}$ was analyzed digesting a $0.2 \mathrm{~g}$ leaf sample with $6 \mathrm{ml}$ of 5:2 $\mathrm{HNO}_{3}: \mathrm{HClO}_{4}$ (Yoshida et al., 1976). Grain and straw samples from each plot (200 $\mathrm{mg})$ were taken and separately oven dried at $65^{\circ} \mathrm{C}$ over night to grind in a grinding machine. Total $\mathrm{N}$ content was determined by Micro-kjeldahl distillation. Total $\mathrm{N}$ uptake was determined by the following formulae:

Nitrogen uptakeby grain $\left(\mathrm{kg} \mathrm{ha}^{-1}\right)=$

$\% \mathrm{~N}$ in grain $\mathrm{x}$ Grain yield $\left(\mathrm{kg} \mathrm{ha}^{-1}\right)$ 100

Nitrogen uptakeby straw $\left(\mathrm{kg} \mathrm{ha}^{-1}\right)=$ $\% \mathrm{~N}$ in straw $\mathrm{x}$ straw y ield $\left(\mathrm{kg} \mathrm{ha}^{-1}\right)$ 100

Nutrient use efficiencies were calculated using the following formula (Fageria et al., 1997):

Nutrient use efficiency $=\frac{\left(G_{f}-G_{u}\right)}{N_{a}}$

where, $G_{f}$ is the grain yield of the fertilized plot $(\mathrm{kg}), \mathrm{G}_{\mathrm{u}}$ is the grain yield of the unfertilized plot $(\mathrm{kg})$ and $\mathrm{N}_{\mathrm{a}}$ is the quantity of nutrient applied $(\mathrm{kg})$.

\subsection{Statistical analysis}

The data of different parameters were analyzed statistically by a statistical procedure of analysis of variance (ANOVA). Microsoft Excel and software program were used whenever appropriate to perform statistical analysis. Duncan's Multiple Range (DMRT) Test was used to compare means at 0.05 level of significance.

\section{Results and Discussion}

\subsection{Nitrogen content, uptake and use efficiency}

Nitrogen concentration was maximum $(0.83 \%)$ in rice plants under the application of higher dose of fertilizer at closer plant spacing (Table 1). Similar result was observed by Khanam et al. (2000) who reported that nitrogen content in rice plant increased with the increase of fertilizer dose and at closer plant spacing. But Shehu et al. (2010) reported that nitrogen content in rice plant increased under higher dose of fertilizer with wider plant spacing. On the other hand, minimum $(0.78 \%)$ was found with the application of the lower dose of fertilizer at wider plant spacing. Higher amount of nitrogen concentration in rice plants at higher dose of fertilizer indicated that the new rice variety required higher amount of nitrogen to sustain maximum growth rate. Havlin et al. (2006) observed that when a nutrient is deficient, increasing nutrient availability at higher fertilizer dose will increase plant nutrient contents. Further, application of other nutrients also increases plant nitrogen content as Mugwira et al. (1997) reported that application phosphorus increased shoot nitrogen content of plant. Because phosphorus plays a role in uptake and utilization of nitrogen by developing extensive roots through which nitrogen can be absorbed and distributed to other parts of the plant.

Nitrogen uptake by rice plant under higher dose of applied fertilizer with closer spacing was the highest $\left(86.53 \mathrm{~kg} \mathrm{ha}^{-1}\right)$ and the lowest nitrogen uptake $\left(50.54 \mathrm{~kg} \mathrm{ha}^{-1}\right)$ was observed in lower dose of applied fertilizer with wider spacing. This confirms the findings of Mahato et al. (2007) who explained that higher level of fertilizer dose and plant spacing increased dry matter yield per unit area and ultimately increased nitrogen uptake over lower fertilizer dose and wider plant spacing.

Application of lower dose fertilizer with wider plant spacing showed the highest $(65.49 \mathrm{~kg}$ grain per kg N uptake) nitrogen use efficiency. On the other hand, the lowest nitrogen use efficiency (59.87 kg grain per $\mathrm{kg} \mathrm{N}$ uptake) was recorded at high level of fertilizer dose with closer planting spacing. Liu et al. (2016) also observed decrease of nitrogen use efficiency due to use of high level of $\mathrm{N}$ fertilizer and inappropriate fertilization management in rice cultivation. In this context, Jiang et al. (2013) explained that, narrow spacing of rice plant decreases nitrogen use efficiency, because of excessive absorption 
of nitrogen under higher fertilizer level. In closer spacing most of the nitrogen was accumulated in the vegetative organs and few were translocated to the grains, which decreases nitrogen use efficiency in rice (Mae et al., 2006).

Table 1. Nitrogen content, uptake and use efficiency of new aromatic rice variety BUdhan 2 as influenced by different level of fertilizer dose and plant spacing

\begin{tabular}{|c|c|c|c|c|}
\hline $\begin{array}{c}\text { Fertilizer level } \\
\left(\text { N P K S Zn kg ha }{ }^{-1}\right)\end{array}$ & $\begin{array}{l}\text { Spacing } \\
\quad(\mathrm{cm})\end{array}$ & $\begin{array}{c}\text { Nitrogen } \\
\text { content }(\%)\end{array}$ & $\begin{array}{l}\text { Nitrogen } \\
\text { uptake } \\
\left(\mathrm{kg} \mathrm{ha}^{-1}\right)\end{array}$ & $\begin{array}{c}\text { Nitrogen use efficiency } \\
\text { (kg grain per kg N } \\
\text { uptake) }\end{array}$ \\
\hline \multirow{3}{*}{$\begin{array}{c}\text { Higher dose } \\
(114-20-16-14-1.8)\end{array}$} & Wide $(20 \times 25)$ & $0.81 \mathrm{a}$ & $62.46 \mathrm{de}$ & $61.54 \mathrm{ab}$ \\
\hline & Standard $(20 \times 20)$ & $0.82 \mathrm{a}$ & $67.27 \mathrm{~cd}$ & $60.84 \mathrm{ab}$ \\
\hline & Closer $(20 \times 15)$ & $0.83 \mathrm{a}$ & $86.53 \mathrm{a}$ & $59.87 \mathrm{~b}$ \\
\hline \multicolumn{2}{|c|}{ Mean of higher doses of different plant spacing } & $0.82 \mathrm{a}$ & $72.08 \mathrm{a}$ & $60.75 \mathrm{~b}$ \\
\hline \multirow{3}{*}{$\begin{array}{l}\text { Recommended dose } \\
(57-10-8-7-0.9)\end{array}$} & Wide $(20 \times 25)$ & $0.80 \mathrm{a}$ & $54.70 \mathrm{f}$ & $63.08 \mathrm{ab}$ \\
\hline & Standard $(20 \times 20)$ & $0.80 \mathrm{a}$ & $64.12 \mathrm{de}$ & $62.85 \mathrm{ab}$ \\
\hline & Closer $(20 \times 15)$ & $0.81 \mathrm{a}$ & $77.53 \mathrm{~b}$ & $61.01 \mathrm{ab}$ \\
\hline \multicolumn{2}{|c|}{$\begin{array}{c}\text { Mean of recommended doses of different plant } \\
\text { spacing }\end{array}$} & $0.80 \mathrm{a}$ & $65.45 \mathrm{~b}$ & $61.32 \mathrm{ab}$ \\
\hline \multirow{3}{*}{$\begin{array}{c}\text { Lower dose } \\
(28.5-5-4-3.5-0.45)\end{array}$} & Wide $(20 \times 25)$ & $0.78 \mathrm{a}$ & $50.54 \mathrm{f}$ & $65.49 \mathrm{a}$ \\
\hline & Standard $(20 \times 20)$ & $0.79 \mathrm{a}$ & $61.22 \mathrm{e}$ & $63.06 \mathrm{ab}$ \\
\hline & Closer $(20 \times 15)$ & $0.79 \mathrm{a}$ & $70.66 \mathrm{c}$ & $62.69 \mathrm{ab}$ \\
\hline \multicolumn{2}{|c|}{ Mean of lower doses of different plant spacing } & $0.79 \mathrm{a}$ & $60.81 \mathrm{c}$ & $63.75 \mathrm{a}$ \\
\hline \multicolumn{2}{|c|}{$\mathrm{CV}(\%)$} & 6.78 & 5.77 & 5.22 \\
\hline \multicolumn{2}{|l|}{$\operatorname{LSD}(0.05 \%)$} & 0.0794 & 5.5676 & 4.7467 \\
\hline
\end{tabular}

Means in a column followed by same letter (s) did not differ significantly by DMRT at 0.05 level

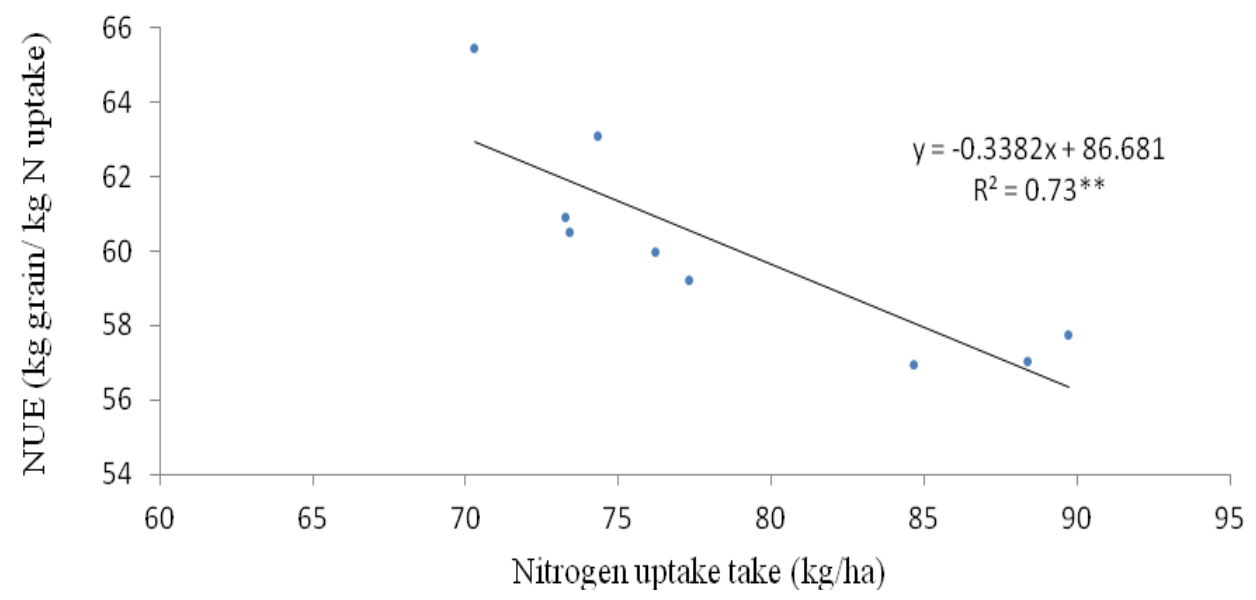

Figure 1. Functional relationship between $\mathrm{N}$ uptake and $\mathrm{N}$ use efficiency of new aromatic rice variety BUdhan 2 as influenced by variable fertilizer dose and plant spacing.

* indicates significant at $5 \%$ level of probability 
The result confirms with the functional relationship (Fig. 1) between nitrogen uptake and nitrogen use efficiency that nitrogen use efficiency decreases with the increase of nitrogen uptake by the rice plant.

\subsection{Phosphorus content, uptake and use efficiency}

Application of higher amount of fertilizer increased phosphorus content in rice plant. The maximum phosphorus concentration $(0.089 \%)$, in rice plants was found with the application of the higher dose of fertilizer and it was profoundly influenced by plant density. The minimum $(0.083 \%$, ) was obtained at lower dose of fertilizer in wider plant spacing, which indicated that phosphorus availability was not sufficient for rice plant at lower fertilizer dose. Low availability of phosphorus in soil showed down phosphorus absorption which reduces phosphorus concentration in rice plant (Tandon, 1995).

As phosphorus content increases at higher fertilizer dose, the highest phosphorus uptake $\left(9.85 \mathrm{~kg} \mathrm{ha}^{-1}\right.$ ) was found under higher dose of fertilizer with closer plant spacing (Table 2). The lowest phosphorus uptake $\left(6.0 \mathrm{~kg} \mathrm{ha}^{-1}\right)$ was observed in rice plants grown under lower dose of fertilizer with wider plant spacing. In present study, phosphorus uptake further influenced by application of higher amount of other element especially from increase in nitrogen rate. Sieling et al. (2006) reported that nitrogen promote phosphorus uptake by increasing tap root growth, plant metabolism, phosphorus solubility and availability of phosphorus by decreasing the soil $\mathrm{pH}$ through $\mathrm{NH}_{4}{ }^{+}$absorption.

Table 2. Phosphorus content, uptake and use efficiency of new aromatic rice variety BUdhan 2 as influenced by different level of fertilizer dose and plant spacing

\begin{tabular}{|c|c|c|c|c|}
\hline $\begin{array}{c}\text { Fertilizer level } \\
(\mathrm{N} \mathrm{P} \mathrm{K} \mathrm{S} \mathrm{Zn} \mathrm{kg} \mathrm{ha}\end{array}$ & $\begin{array}{l}\text { Spacing } \\
\text { (cm) }\end{array}$ & $\begin{array}{l}\text { Phosphorus } \\
\text { content } \\
(\%)\end{array}$ & $\begin{array}{c}\text { Phosphorus } \\
\text { uptake } \\
\left(\mathrm{kg} \mathrm{ha}^{-1}\right)\end{array}$ & $\begin{array}{c}\text { Phosphorus } \\
\text { use efficiency } \\
\text { (kg grain per kg } \\
\text { P uptake) }\end{array}$ \\
\hline \multirow{3}{*}{$\begin{array}{c}\text { Higher dose } \\
(114-20-16-14-1.8)\end{array}$} & Wide $(20 \times 25)$ & $0.085 \mathrm{a}$ & $6.94 \mathrm{e}$ & $547.44 \mathrm{a}$ \\
\hline & Standard $(20 \times 20)$ & $0.084 \mathrm{a}$ & $7.75 \mathrm{~cd}$ & $534.22 \mathrm{a}$ \\
\hline & Closer $(20 \times 15)$ & $0.089 \mathrm{a}$ & $9.85 \mathrm{a}$ & $521.58 \mathrm{a}$ \\
\hline \multicolumn{2}{|c|}{ Mean of higher doses of different plant spacing } & $0.086 \mathrm{a}$ & $8.18 \mathrm{a}$ & $549.00 \mathrm{a}$ \\
\hline \multirow{3}{*}{$\begin{array}{l}\text { Recommended dose } \\
(57-10-8-7-0.9)\end{array}$} & Wide $(20 \times 25)$ & $0.084 \mathrm{a}$ & $6.27 \mathrm{f}$ & $550.55 \mathrm{a}$ \\
\hline & Standard $(20 \times 20)$ & $0.089 \mathrm{a}$ & $7.4 \mathrm{de}$ & $544.39 \mathrm{a}$ \\
\hline & Closer $(20 \times 15)$ & $0.08 \mathrm{a}$ & $9.07 \mathrm{~b}$ & $521.76 \mathrm{a}$ \\
\hline \multicolumn{2}{|c|}{$\begin{array}{l}\text { Mean of recommended doses of different plant } \\
\text { spacing }\end{array}$} & $0.084 \mathrm{a}$ & $7.58 \mathrm{~b}$ & 538.90 a \\
\hline \multirow{3}{*}{$\begin{array}{c}\text { Lower dose } \\
(28.5-5-4-3.5-0.45)\end{array}$} & Wide $(20 \times 25)$ & $0.083 \mathrm{a}$ & $6 \mathrm{f}$ & $551.82 \mathrm{a}$ \\
\hline & Standard $(20 \times 20)$ & $0.084 \mathrm{a}$ & $7.03 \mathrm{e}$ & $549.29 \mathrm{a}$ \\
\hline & Closer $(20 \times 15)$ & $0.085 \mathrm{a}$ & $8.12 \mathrm{c}$ & $545.89 \mathrm{a}$ \\
\hline \multicolumn{2}{|c|}{ Mean of lower doses of different plant spacing } & $0.084 \mathrm{a}$ & $7.05 \mathrm{c}$ & $53441 \mathrm{a}$ \\
\hline \multicolumn{2}{|l|}{$\mathrm{CV}(\%)$} & 8.29 & 5.80 & 8.84 \\
\hline \multicolumn{2}{|l|}{$\operatorname{LSD}(0.05 \%)$} & 0.0102 & 0.6437 & 69.800 \\
\hline
\end{tabular}




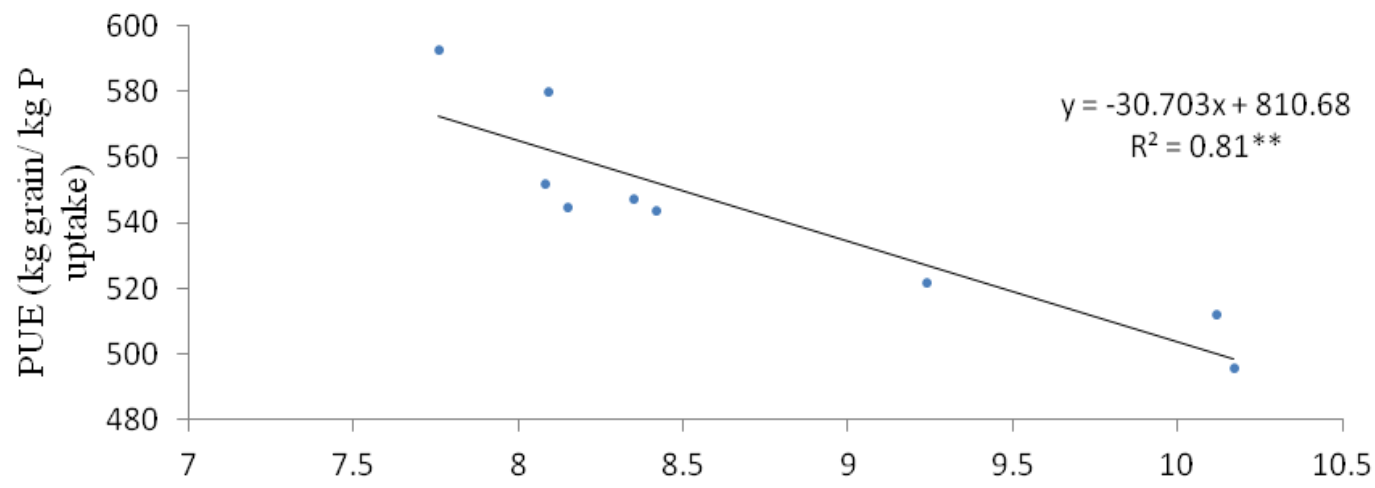

Phosphprus uptake (kg/ha)

Figure 2. Functional relationship between $\mathrm{P}$ uptake and $\mathrm{P}$ use efficiency of new aromatic rice variety BUdhan 2 as influenced by applied fertilizer rate and plant spacing. ** indicates significant at $1 \%$ level of probability.

Table 3. Potassium content, uptake and use efficiency of new aromatic rice variety BUdhan 2 as influenced by different level of fertilizer dose and plant spacing.

\begin{tabular}{|c|c|c|c|c|}
\hline $\begin{array}{c}\text { Fertilizer level } \\
(\mathrm{N} \mathrm{P} \mathrm{K} \mathrm{S} \mathrm{Zn} \mathrm{kg} \mathrm{ha}\end{array}$ & $\begin{array}{l}\text { Spacing } \\
\quad(\mathrm{cm})\end{array}$ & $\begin{array}{c}\text { Potassium } \\
\text { Content } \\
(\%)\end{array}$ & $\begin{array}{l}\text { Potassium } \\
\text { uptake } \\
\left(\mathrm{kg} \mathrm{ha}^{-1}\right)\end{array}$ & $\begin{array}{c}\text { Potassium } \\
\text { use efficiency } \\
\text { (kg grain per kg } \\
\text { K uptake) }\end{array}$ \\
\hline \multirow{3}{*}{$\begin{array}{c}\text { Higher dose } \\
(114-20-16-14-1.8)\end{array}$} & Wide $(20 \times 25)$ & $0.17 \mathrm{a}$ & $72.06 \mathrm{de}$ & $52.74 \mathrm{a}$ \\
\hline & Standard $(20 \times 20)$ & $0.17 \mathrm{a}$ & $80.51 \mathrm{c}$ & $51.42 \mathrm{a}$ \\
\hline & Closer $(20 \times 15)$ & $0.18 \mathrm{a}$ & $103.9 \mathrm{a}$ & $49.86 \mathrm{a}$ \\
\hline \multicolumn{2}{|c|}{ Mean of higher doses of different plant spacing } & $0.17 \mathrm{a}$ & $0.85 .48 \mathrm{a}$ & $51.57 \mathrm{a}$ \\
\hline \multirow{3}{*}{$\begin{array}{l}\text { Recommended dose } \\
(57-10-8-7-0.9)\end{array}$} & Wide $(20 \times 25)$ & $0.17 \mathrm{a}$ & 65.14 ef & $52.96 \mathrm{a}$ \\
\hline & Standard $(20 \times 20)$ & $0.16 \mathrm{a}$ & $77.74 \mathrm{~cd}$ & $51.84 \mathrm{a}$ \\
\hline & Closer $(20 \times 15)$ & $0.16 \mathrm{a}$ & $92.91 \mathrm{~b}$ & $50.91 \mathrm{a}$ \\
\hline \multicolumn{2}{|c|}{$\begin{array}{l}\text { Mean of recommended doses of different plant } \\
\text { spacing }\end{array}$} & $0.16 \mathrm{a}$ & $78.60 \mathrm{~b}$ & $51.90 \mathrm{a}$ \\
\hline \multirow{3}{*}{$\begin{array}{c}\text { Lower dose } \\
(28.5-5-4-3.5-0.45)\end{array}$} & Wide $(20 \times 25)$ & $0.15 \mathrm{a}$ & $61.1 f$ & $54.18 \mathrm{a}$ \\
\hline & Standard $(20 \times 20)$ & $0.16 \mathrm{a}$ & $71.57 \mathrm{de}$ & $53.93 \mathrm{a}$ \\
\hline & Closer $(20 \times 15)$ & $0.16 \mathrm{a}$ & $84.23 \mathrm{c}$ & $52.59 \mathrm{a}$ \\
\hline \multicolumn{2}{|c|}{ Mean of lower doses of different plant spacing } & $0.16 \mathrm{a}$ & $72.30 \mathrm{c}$ & $53.57 \mathrm{a}$ \\
\hline \multicolumn{2}{|l|}{$\mathrm{CV}(\%)$} & 8.46 & 5.10 & 9.66 \\
\hline \multicolumn{2}{|l|}{$\operatorname{LSD}(0.05 \%)$} & 0.0203 & 5.8645 & 7.3705 \\
\hline
\end{tabular}

Means in a column followed by same letter (s) did not differ significantly by DMRT at 0.05 level. 


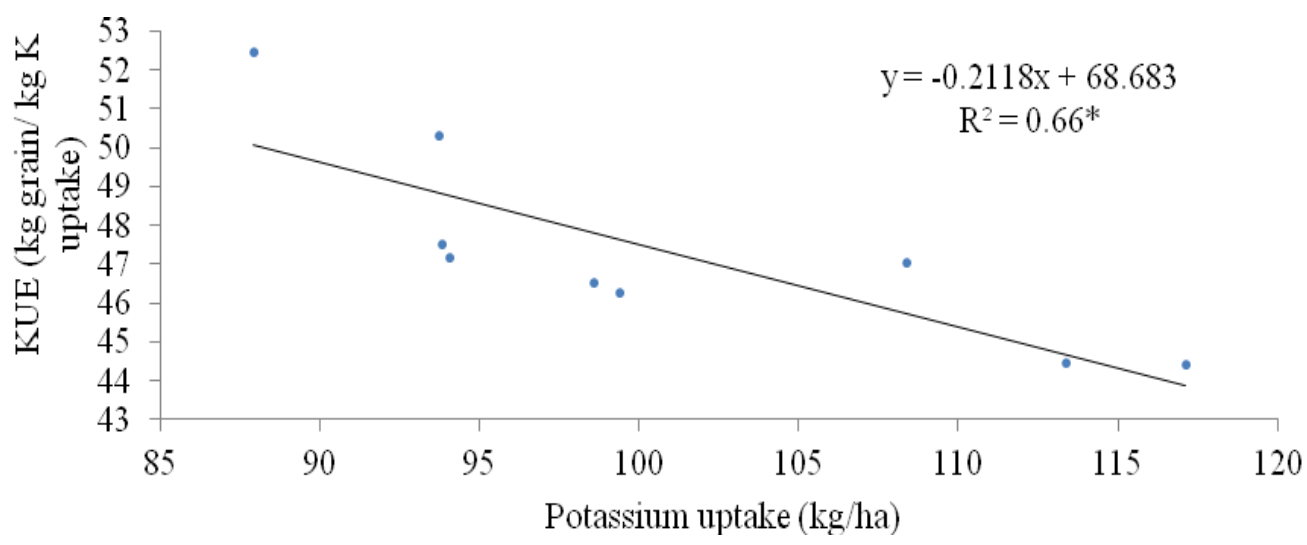

Figure 3. Functional relationship between $\mathrm{K}$ uptake and $\mathrm{K}$ use efficiency of new aromatic rice variety BUdhan 2 as influenced by applied fertilizer rate and plant spacing. * indicates significant at $5 \%$ level of probability.

Phosphorus use efficiency also decreased with the increase of the level of fertilizer dose and decrease of plant spacing. Phosphorus use efficiency was the lowest $(521.58 \mathrm{~kg}$ grain per $\mathrm{kg} \mathrm{P}$ uptake) under high fertilizer dose with closer plant spacing and the highest phosphorus use efficiency (551.82 $\mathrm{kg}$ grain per $\mathrm{kg} \mathrm{P}$ uptake) was recorded under low level of fertilizer dose with wider plant spacing. Venugopalan and Blaise (2001) also reported that phosphorus uptake greatly influences on phosphorus use efficiency and there is negative relationship (Fig. 2) between phosphorus uptake and phosphorus use efficiency in rice plants in present study.

\subsection{Potassium content, uptake and use efficiency}

Application of higher dose of fertilizer did not increase plant potassium content significantly but it tended to increase to some extent (Table 3). However, potassium uptake increased at higher fertilizer dose and closer plant spacing. Maximum amount $\left(103.9 \mathrm{~kg} \mathrm{ha}^{-1}\right)$ of potassium uptake was recorded at higher fertilizer with closer spacing. The application of potassium through higher fertilizer rate promoted greater availability of potassium in the soil, and consequently, the contact between potassium and the rice roots (Filho et al., 2017). Potassium use efficiency was the highest $(54.18 \mathrm{~kg}$ grain per $\mathrm{kg}$
$\mathrm{K}$ uptake) at lower fertilizer dose in wider plant spacing and the lowest (49.86 kg grain per $\mathrm{kg} \mathrm{K}$ uptake) at higher fertilizer dose with closer plant spacing. Similar result was found by Filho (2017) who observed the highest potassium use efficiency with the application of lower dose of potassium fertilizer. However, much decrease in potassium use efficiency is not consistent as it is not a part of structural organs of the plant. Decrease in potassium use efficiency (Fig.3) with increasing potassium uptake in rice also illustrated in present study.

\subsection{Sulphur content, uptake and use efficiency} Sulphur content in rice plants increased under higher fertilizer dose (Table 4) as higher fertilizer dose contains higher amount of other elements including sulphur. This increase in sulphur content may be due to its stimulation of root and shoot growth. Sanju et al. (2005) reported that plants with well-developed root systems have the ability to exploit a greater soil volume which is fundamental for increasing the contact between roots and nutrients resulting in an improvement in sulphur content and sulphur uptake. Sulphur uptake further enhanced by plant density where closer spacing increased sulphur uptake in rice. Thus maximum content $(0.066 \%)$ and uptake $\left(12.27 \mathrm{~kg} \mathrm{ha}^{-1}\right)$ of sulphur was recorded at higher fertilizer level with closer 
plant spacing. Sulphur use efficiency however decreased with the increase of fertilizer dose and plant spacing as there is negative relationship
(Fig. 4) between sulphur uptake and sulphur use efficiency in rice.

Table 4. Sulphur content, uptake and use efficiency of new aromatic rice variety BUdhan 2 as influenced by variable fertilizer dose and plant spacing

\begin{tabular}{|c|c|c|c|c|}
\hline $\begin{array}{c}\text { Fertilizer level } \\
\left(\mathrm{N} \mathrm{P} \mathrm{K} \mathrm{S} \mathrm{Zn} \mathrm{kg} \mathrm{ha}^{-1}\right)\end{array}$ & $\begin{array}{l}\text { Spacing } \\
\quad(\mathrm{cm})\end{array}$ & $\begin{array}{c}\text { Sulphur } \\
\text { content } \\
(\%)\end{array}$ & $\begin{array}{l}\text { Sulphur } \\
\text { uptake } \\
\left.(\mathrm{kg} \mathrm{ha})^{-1}\right)\end{array}$ & $\begin{array}{c}\text { Sulphur use } \\
\text { efficiency } \\
\text { (kg grain per kg } \\
\text { S uptake) }\end{array}$ \\
\hline \multirow{3}{*}{$\begin{array}{c}\text { Higher dose } \\
(114-20-16-14-1.8)\end{array}$} & Wide $(20 \times 25)$ & $0.063 \mathrm{a}$ & $8.28 \mathrm{~cd}$ & $458.98 \mathrm{~b}$ \\
\hline & Standard $(20 \times 20)$ & $0.064 \mathrm{a}$ & $9.62 \mathrm{bc}$ & $430.43 \mathrm{c}$ \\
\hline & Closer $(20 \times 15)$ & $0.066 \mathrm{a}$ & $12.27 \mathrm{a}$ & $422.28 \mathrm{c}$ \\
\hline \multicolumn{2}{|c|}{ Mean of higher doses of different plant spacing } & $0.064 \mathrm{a}$ & $10.06 \mathrm{a}$ & $437.22 \mathrm{~b}$ \\
\hline \multirow{3}{*}{$\begin{array}{l}\text { Recommended dose } \\
(57-10-8-7-0.9)\end{array}$} & Wide $(20 \times 25)$ & $0.063 \mathrm{a}$ & $7.29 \mathrm{de}$ & $473 \mathrm{~b}$ \\
\hline & Standard $(20 \times 20)$ & $0.063 \mathrm{a}$ & 8.64 bcd & $66.32 \mathrm{~b}$ \\
\hline & Closer $(20 \times 15)$ & $0.066 \mathrm{a}$ & $10.22 \mathrm{~b}$ & $462.85 \mathrm{~b}$ \\
\hline \multicolumn{2}{|c|}{$\begin{array}{l}\text { Mean of recommended doses of different plant } \\
\text { spacing }\end{array}$} & $0.064 \mathrm{a}$ & $8.72 \mathrm{~b}$ & $467.39 \mathrm{ab}$ \\
\hline \multirow{3}{*}{$\begin{array}{c}\text { Lower dose } \\
(28.5-5-4-3.5-0.45)\end{array}$} & Wide $(20 \times 25)$ & $0.061 \mathrm{a}$ & $6.54 \mathrm{e}$ & $505.86 \mathrm{a}$ \\
\hline & Standard $(20 \times 20)$ & $0.062 \mathrm{a}$ & 8.05 cde & $479.23 \mathrm{~b}$ \\
\hline & Closer $(20 \times 15)$ & $0.063 \mathrm{a}$ & $9.35 \mathrm{bc}$ & $473.62 \mathrm{~b}$ \\
\hline \multicolumn{2}{|c|}{ Mean of lower doses of different plant spacing } & $0.062 \mathrm{a}$ & $7.98 \mathrm{c}$ & $486.23 \mathrm{a}$ \\
\hline \multicolumn{2}{|c|}{$\mathrm{CV}(\%)$} & 7.71 & 4.90 & 9.08 \\
\hline \multicolumn{2}{|l|}{$\operatorname{LSD}(0.05 \%)$} & 7.132 & 0.6381 & 61.422 \\
\hline
\end{tabular}

Means in a column followed by same letter (s) did not differ significantly by DMRT at 0.05 level.

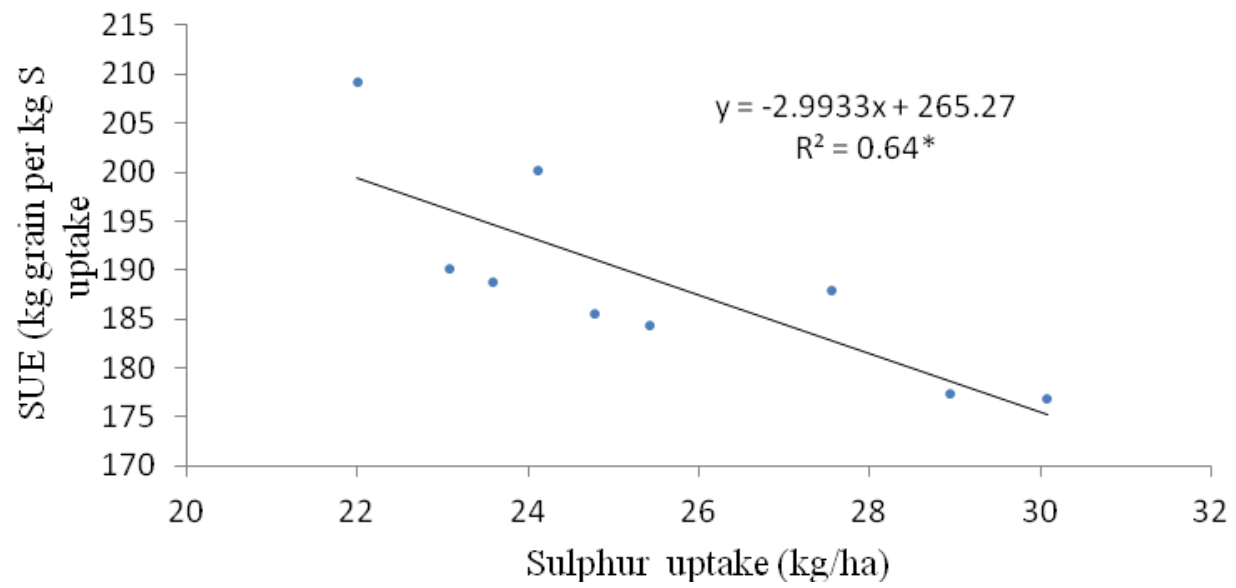

Figure 4. Functional relationship between $S$ uptake and $S$ use efficiency of new aromatic rice variety BUdhan 2 as influenced by applied fertilizer dose and plant spacing.* indicates significant at $5 \%$ level of probability. 
Table 5. Zinc content, uptake and use efficiency of new aromatic rice variety BUdhan 2 as influenced variable fertilizer dose and plant spacing

\begin{tabular}{|c|c|c|c|c|}
\hline $\begin{array}{c}\text { Fertilizer level } \\
(\text { N P K S Zn kg ha }\end{array}$ & $\begin{array}{l}\text { Spacing } \\
\quad(\mathrm{cm})\end{array}$ & $\begin{array}{c}\text { Zinc } \\
\text { content } \\
\left(\mu \mathrm{g} \mathrm{g}^{-1}\right)\end{array}$ & $\begin{array}{l}\text { Zn uptake } \\
\left(\mathrm{g} \mathrm{ha}^{-1}\right)\end{array}$ & $\begin{array}{c}\text { Zn use } \\
\text { efficiency (kg } \\
\text { grain per g Zn } \\
\text { uptake) }\end{array}$ \\
\hline \multirow{3}{*}{$\begin{array}{c}\text { Higher dose } \\
(114-20-16-14-1.8)\end{array}$} & Wide $(20 \times 25)$ & $81.74 a$ & 180.9 bcde & $21.00 \mathrm{f}$ \\
\hline & Standard $(20 \times 20)$ & $82.40 \mathrm{a}$ & $206.37 \mathrm{bc}$ & $20.06 \mathrm{~g}$ \\
\hline & Closer $(20 \times 15)$ & $83.99 \mathrm{a}$ & $265.76 \mathrm{a}$ & $19.49 \mathrm{~h}$ \\
\hline \multicolumn{2}{|c|}{ Mean of higher doses of different plant spacing } & $82.71 \mathrm{a}$ & $217.67 \mathrm{a}$ & $20.18 \mathrm{~b}$ \\
\hline \multirow{3}{*}{$\begin{array}{l}\text { Recommended dose } \\
(57-10-8-7-0.9)\end{array}$} & Wide $(20 \times 25)$ & $80.91 \mathrm{a}$ & $158.99 \mathrm{de}$ & $21.69 \mathrm{~d}$ \\
\hline & Standard $(20 \times 20)$ & $81.89 \mathrm{a}$ & $186 \mathrm{bcd}$ & $21.66 \mathrm{~d}$ \\
\hline & Closer $(20 \times 15)$ & $82.98 \mathrm{a}$ & $220.7 \mathrm{~b}$ & $21.43 \mathrm{e}$ \\
\hline \multicolumn{2}{|c|}{$\begin{array}{l}\text { Mean of recommended doses of different plant } \\
\text { spacing }\end{array}$} & $81.93 \mathrm{a}$ & $188.56 \mathrm{~b}$ & $21.60 \mathrm{ab}$ \\
\hline \multirow{3}{*}{$\begin{array}{c}\text { Lower dose } \\
(28.5-5-4-3.5-0.45)\end{array}$} & Wide $(20 \times 25)$ & $81.74 \mathrm{a}$ & $144.16 \mathrm{e}$ & $22.96 \mathrm{a}$ \\
\hline & Standard $(20 \times 20)$ & $82.40 \mathrm{a}$ & 173.10 cde & $22.29 \mathrm{~b}$ \\
\hline & Closer $(20 \times 15)$ & $83.99 \mathrm{a}$ & $203.42 \mathrm{bc}$ & $21.77 \mathrm{c}$ \\
\hline \multicolumn{2}{|c|}{ Mean of lower doses of different plant spacing } & $82.71 \mathrm{a}$ & $173.56 \mathrm{c}$ & $22.34 \mathrm{a}$ \\
\hline \multicolumn{2}{|c|}{$\mathrm{CV}(\%)$} & 7.90 & 5.79 & 9.36 \\
\hline \multicolumn{2}{|l|}{$\operatorname{LSD}(0.05 \%)$} & 9.5001 & 16.340 & 2.9180 \\
\hline
\end{tabular}

Means in a column followed by same letter (s) did not differ significantly by DMRT at 0.05 level

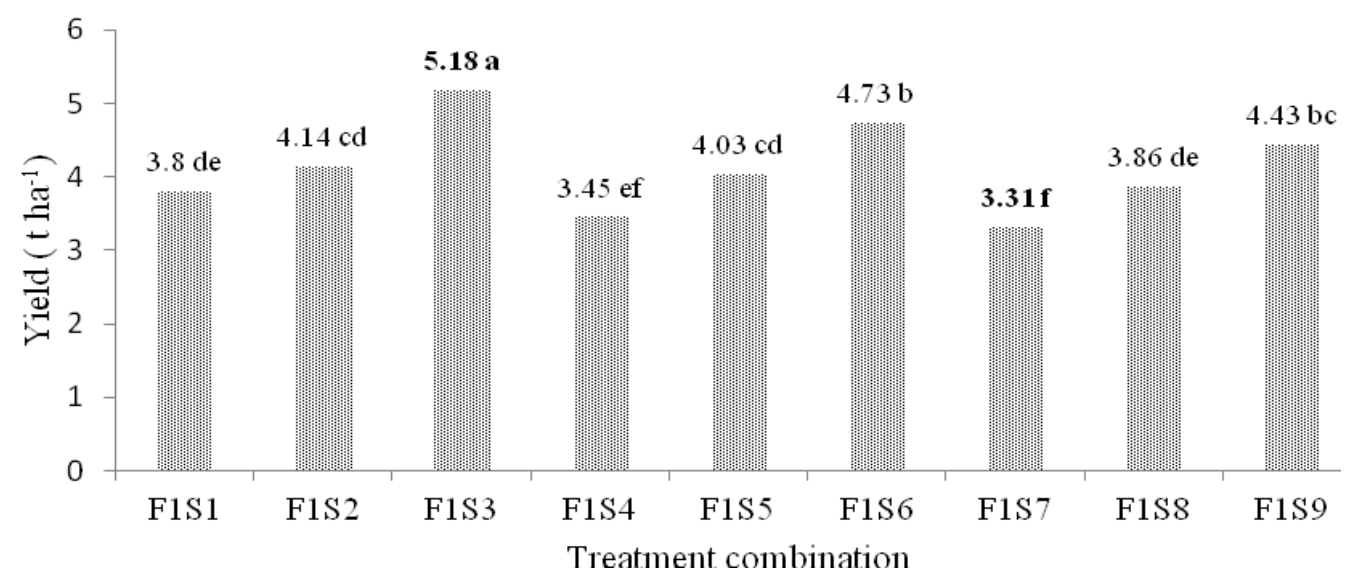

Figure 5. Grain yield of new aromatic rice variety BUdhan 2 as influenced by variable fertilizer dose and plant spacing

\subsection{Zinc content, uptake and use efficiency}

Zinc concentration in rice plants did not vary significantly due to levels of fertilizer and plant spacing (Table 5). However, higher zinc concentration in rice plant was observed under higher fertilizer level over the plant spacing. Zinc accumulation pattern in plant is genetic characteristics that control the variability of specific carrier involved in ion uptake through the plasmatic membrane of root cell. The 
specificity and selectivity of this carrier are directly related to mineral uptake and fertilizer use efficiency (Fageria, 2011). Although zinc uptake by rice plant was higher $\left(265.76 \mathrm{~g} \mathrm{ha}^{-1}\right)$ in higher fertilizer level and closer plant spacing but zinc use efficiency $(22.96 \mathrm{~kg}$ grain per $\mathrm{g} \mathrm{Zn}$ uptake) was the highest under lower fertilizer level with wider plant spacing. This result agreed well with the findings of Zand et al. (2014) in sorghum and Ghoneim (2016) in rice.

\section{Conclusions}

The highest uptake of nitrogen $\left(86.53 \mathrm{~kg} \mathrm{ha}^{-1}\right)$, phosphorus $\left(9.85 \mathrm{~kg} \mathrm{ha}^{-1}\right)$, potassium $(103.9 \mathrm{~kg}$ $\left.\mathrm{ha}^{-1}\right)$, sulphur $\left(12.27 \mathrm{~kg} \mathrm{ha}^{-1}\right)$ and zinc $(265.76 \mathrm{~g}$ $\mathrm{ha}^{-1}$ ) was found under higher dose of applied fertilizer with closer spacing was the maximum. On the other hand, the minimum uptake of nitrogen $\left(50.54 \mathrm{~kg} \mathrm{ha}^{-1}\right)$, phosphorus $\left(6.0 \mathrm{~kg} \mathrm{ha}^{-}\right.$ $\left.{ }^{1}\right)$, potassium $\left(61.1 \mathrm{~kg} \mathrm{ha}^{-1}\right)$, sulphur $\left(6.54 \mathrm{~kg} \mathrm{ha}^{-}\right.$ ${ }^{1}$ ) and zinc (144.16 $\left.\mathrm{g} \mathrm{ha}^{-1}\right)$ was observed under lower dose of applied fertilizer with wider spacing. Comparing the nutrient use efficiency among all nine treatments, lower dose of applied fertilizer with closer plant spacing showed the highest nutrient use efficiency of nitrogen (65.49 $\mathrm{kg}$ grain per $\mathrm{kg} \mathrm{N}$ uptake), phosphorus (551.82 $\mathrm{kg}$ grain per $\mathrm{kg} \mathrm{P}$ uptake), potassium $(54.18 \mathrm{~kg}$ grain per $\mathrm{kg} \mathrm{K}$ uptake), sulphur (505.86 kg grain per $\mathrm{kg} \mathrm{S}$ uptake) and zinc (22. $96 \mathrm{~kg}$ grain per $\mathrm{g}$ Zn uptake).

\section{Recommendations}

To accelerate the nutrient uptake $\left(\mathrm{kg} \mathrm{ha}^{-1}\right)$ of the variety BUdhan 2 for the yield of more than $5 \mathrm{t}$ $\mathrm{ha}^{-1}$, higher fertilizer dose of 114-20-16-14-1.8 $\mathrm{kg} \mathrm{NPKSZn} \mathrm{ha}{ }^{-1}$ at plant spacing of $20 \mathrm{~cm} \mathrm{x} 15$ $\mathrm{cm}$ is recommended.

\section{References}

Ahmed N. 1992. Efficient use of plant nutrients, Proc. $4^{\text {th }}$ Nat. Cong. May 24-26, Islamabad, 2-22 pp.

BBS (Bangladesh Bureau of Statistics). 2015. Yearbook of Agricultural Statistics,
Bangladesh, $27^{\text {th }}$ Series, Ministry of Planning, Government of People's Republic of Bangladesh. $49 \mathrm{p}$.

Bhuiyan NI., Salam MA. 2004. Research Development of Boro Rice in Bangladesh, A plant breeding prospective of Boro Rice. Indian Agricultural Research Institute, India, 43- $49 \mathrm{pp}$.

Dobermann A., Cruz C. and Cassman K.G. 1996. Fertilizer inputs, nutrient balance, and soil nutrient-supplying power in intensive irrigated system and Potassium uptake and K balance. Nutrient. Cycling Agroecosystem, 46: 1-10.

Fageria NK., Baligar VC., Jones CA. 2011. Growth and mineral nutrition on root growth of crop plants. Advances in Agronomy, 251-331p.

Fageria NK., Baligar VC., Jones CA. 1997. Growth and mineral nutrition of field crops. $2^{\text {nd }}$ Ed., Marcel Dekker Inc., New York, $49 \mathrm{p}$.

Filho, ACDA., Crusciol CAC., Nascente AS., Mauad M., Garcia RA. 2017. Influence of potassium levels on root growth and nutrient uptake of upland rice cultivars. Review of Caatinga, 30(1):32-44.

Ghoneim, A. M. 2016. Effect of Different Methods of $\mathrm{Zn}$ Application on Rice Growth, Yield and nutrients dynamics in plant and soil. Journal of Agricultural and Ecological Research International, 6 (2): $1-9$.

Havlin JL., Beaton JD., Nelson WI. 2006. Soil fertility and fertilizer an Introduction to Nutrient Management, $7^{\text {th }}$ edition, $515 \mathrm{p}$.

HIES (Household Income and Expenditure Survey). 2010. Bangladesh Bureau of Statistics. Yearbook of Agricultural Statistics, Bangladesh, $27^{\text {th }}$ Series, Ministry of Planning, Government of People's Republic of Bangladesh. 69 p.

Jiang W., Wang K.,Wu Q., Dong S., Liu P., Jiwang Z. 2013. Effects of narrow plant spacing on root distribution and physiological nitrogen use efficiency in 
summer maize. The crop Journal, 1:7783.

Khanam M., Hamid A., Hashem A. 2000. Nitrogen accumulation and grain yield of rice under different plant density and nitrogen application rate. Thai Journal of Agricultural Science, 33:21-28.

Liu X., Wang H., Zhou J., Hu F., Zhu D. Chen Z. 2016. The effect of $\mathrm{N}$ Fertilization Pattern on Rice Yield, N Use Efficiency and Fertilizer-N Fate in the Yangtze River Basin, China.11-29 pp

Mae T., Inaba A., Kaneta Y., Masaki S., Sasaki M., Aizawa M., Okawa S., Hasegawa S. Makino A. 2006. A large-grain rice cultivar, Akita 63, exhibits high yields with high physiological N-use efficiency. Field Crops Research, 97: 227-237.

Mahato P., Gunri SK., Chanda K., Ghosh M. 2007. The effect of varying levels of fertilizer and Spacing on Medium Duration Rice (Oryza sativa L.) in Tarai zone of West Bengal Karnataka. Indian Agricultural Science, 20: 363.

Matti DD., Jana PK. 1985. Effect of different levels of nitrogen and phosphorus on yield and yield attributes of sesame. Indian Oilseed Research, 2: 252-259.

Mugwira I., Haque I., Lapwapi NZ., Layindula N. 1997. Evaluation of phosphorus uptake and use efficiency and nitrogen fixation potential by African clovers Agric. Ecosystem and Environment, 65: 169-175.

Ragland I., Boonpuckdee L., Kongpolprom W. 1987. Fertilizer responses in Northeast Thailand, Soil acidity, phosphorus availability, and water. Thailand. Soils Fertility, 9: 122-130.

Rautaray SK. 2007. Effect of spacing and fertilizer dose on grain yield of rice (Oryza sativa L.) in rice-rice cropping sequence.www.research.net/publication/2 81062551

Sanju UM., Singh BP., Whitehead WF. 2005. Tillage, cover crops and nitrogen fertilization effects on cotton and sorghum root biomass, carbon and nitrogen. Agronomy Journal, 5:1279-1290.

Shehu HE., Kwari JD., Sandabe MK. 2010. Effects of $\mathrm{N}, \mathrm{P}$ and $\mathrm{K}$ fertilizers on yield contents and uptake of $\mathrm{N}, \mathrm{P}$ and $\mathrm{K}$ by sesame (Sesamum indicum). International Journal of Agricultural Biology, 12: 845850 .

Singh AK., Manibhushan A, Meena K., Upadhyaya A. 2012. Effect of Sulphur and Zinc on Rice Performance and Nutrient Dynamics in Plants and Soils of Indo Gangetic Plains. Journal of Agricultural Science, 4(11): 162-169.

Suriya AD., Chaiyawat P., Fukai S., Blamey P. 2000. Identification of Nutrients Limiting Rice Growths in Soils of Northeast Thailand under Water-Limiting and NonLimiting Conditions, Plant Production Science, 3(4): 419-421.

Tandon HLS. 1995. Methods of analysis of plants, soils and water and fertilizers. Fertilizer Development and Con. Org. New Delhi, India, $70 \mathrm{p}$.

Tillman BA., Pan WA., Ulrich SE. 1991. Nitrogen use by Northern-adopted barley genotypes under no till. Agronomy Journal, 83: 194-201.

Yoshida S., Forno DA., Cock JH., Gomez KA. 1976. Laboratory Manual for Physiological Studies of Rice. $3^{\text {rd }}$ ed. International Rice Research Institute, Manila, Philippines, $57 \mathrm{p}$.

Venugopalan, MV., Blaise D. 2001. The effect of planting density and nitrogen levels on productivity and $\mathrm{N}$-use efficiency of rain fed upland cotton (Gossypium hirsutum). Indian Journal of Agronomy, 46: 346-353.

Zand N., Shakiba MR., Vahed MM., Nasab ADM. 2014. Response of sorghum to nitrogen fertilizer at different plant densities. International Journal of Farm Alli Science, 3(1): 71-74. 